\title{
UP THE DOWN ESCALATOR: THE INTRODUCTION OF ACHIEVEMENT STANDARDS IN THE NATIONAL CERTIFICATE OF EDUCATIONAL ACHIEVEMENT
}

\author{
LYDIA AUSTIN \\ School of Education \\ University of Auckland
}

\begin{abstract}
Throughout most of New Zealand's educational history, students have been required to sit written and sometimes oral examinations either as a record of achievement at the end of schooling, as a passport to further free schooling, for the information of potential employers, or as means of acquiring a place in higher education. During the last 122 years New Zealand school children have seen a variety of examinations come and go including examinations carried out during an inspector's visit to a primary school; oral and written post-primary school examinations set by the local university professor; written national examinations originally intended for entry into the civil service: national Matriculation and School Certificate examinations and, more recently University Bursary examinations. The history of these examinations and assessment procedures shows that a new qualification gains acceptance only if it has a certain rarity value. Once that qualification is attainable by most students, there are demands for a new qualification of a higher standard. Thus the sequence of school qualifications is displaced as new qualifications are introduced at a higher level than previously. The proposed introduction of Achievement Standards at levels 1, 2 and 3 of the Qualifications' Framework and the subsequent protestations by a number of secondary school principals that they will look elsewhere for a challenge for their students will, it is argued, result in a further dumbing down of existing qualifications.
\end{abstract}

\section{INTRODUCTION}

Providing school leaving qualifications that reflect the educational achievements of New Zealand students and which are accepted with confidence by parents, employers and tertiary institutions has been beset with problems and controversies throughout the history of formal education in this country. In 1999 the New Zealand Qualifications Authority announced a new system for assessing student performance at levels 1 to 3 (years 11 to 13) of the Qualifications Framework through a mixture of internally and externally assessed achievement standards, in an attempt to combine the perceived advantages of both forms of assessment. In introducing this new system, the established School Certificate examination normally taken in year 11, the internally assessed Sixth Form Certificate (year 12) and the University Bursary and Scholarship examinations taken in year 13 are to be gradually discontinued, beginning in 2002. Students' educational achievements will be assessed in all subjects of the school curriculum that they study at each of the three levels and applied towards the awarding of Achievement Standards. There are on average six Achievement Standards for each subject every year. Approximately half the standards are to be internally assessed. 
The proposed new system echoes a number of concerns which have been expressed throughout New Zealand's history of formal education. The first of these relates to the nature of the assessment. Methods of assessing what a student knows and can do have been a matter of controversy in New Zealand since the late nineteenth century. Many commentators, in different nations and at different periods, have argued that examinations assess only a small proportion of what a student might have learnt. Examinations, they claim, cannot assess what a student can do in a realistic context, and they put undue pressure and restrictions on teachers' delivery of the curriculum (Royal Commission, 1925). These educationists have argued for internal assessment to be carried out by teachers whom they claim are best able to judge a student's real level of performance. Others have argued, equally vehemently, that examinations motivate students to achieve; they provide students with objective evidence of their relative abilities, and assist them in making decisions about further education and employment (Elley \& Livingstone, 1972). Furthermore, it is alleged that examinations eliminate discrimination, nepotism, plagiarism and favouritism based on the school that pupils attend or their social status.

The second controversy concerns the acceptance of the qualifications by parents, employers and tertiary institutions. Public confidence in the results of the assessment is paramount if a qualification is to gain acceptance. The more care that is taken with the process, the more likely it is that this will happen. However, as was noted in 1938, "the greater the public confidence the stronger is the pressure brought to bear on the children by employers, parents and teachers to make them pass. But the greater the pressure, the more children pass and lower falls the standards of the examination" (Beeby, 1938, p. 234).

The third controversy involves the question of how best, in a purportedly democratic and socially equitable society, to recognise the educational achievements of every student. Pupils' interests and abilities vary considerably, and the mode of assessment needs to recognise their different nature. Problems can arise in establishing qualifications that recognise different levels and kinds of attainment (Hodgetts \& Hodgetts, 1999).

Fourthly, every student, and particularly the most able, needs a challenge to achieve to his or her maximum potential. High levels of achievement need to be formally recognised through appropriate qualifications (Morris, 2000, cited in Irwin, 2000).

Finally, employers and tertiary institutions need a means for judging whether prospective employees or students have the necessary level of educational achievement to be likely to succeed in the selected field of employment or study. In limited entry situations, employers and staff in tertiary institutions need to be able to distinguish between students of different educational achievements in a reasonably reliable way.

In the history of assessment in New Zealand, these conflicting demands have resulted in the introduction of qualifications which have, after a few years, been devalued because of mounting public pressure to allow more and more students to attain them. Subsequent demands for qualifications of greater rarity have resulted in the addition of a higher level qualification which has become devalued subsequently. Attempts to insert new unit standards into the framework of existing systems of assessment in schools have, for the most part, failed to gain full acceptance because they have never been in a position of rarity and thus have never been sought after to any great extent. Consequently, they have not gained the confidence of parents or prospective employers. 
This paper suggests that although the proposed system of Achievement Standards is designed to meet some of the criticisms of both unit standards and the existing school examinations, they are subject to the same problems that have beset assessment regimes in the past and are unlikely to provide the definitive solution that was intended.

\section{ASSESSMENT IN THE NINETEENTH CENTURY}

\section{Primary Schools}

From 1878 (when schooling became compulsory for all children from the ages of 7 to 13 ) to the turn of the nineteenth century, most children did not proceed to secondary schooling. Accordingly, the only recognition of educational achievement was the highest "standard" or class they had passed in the course of their schooling. Assignment to particular standards was based on the judgement of an inspector who made an annual visit to each school for this purpose. Assessment was frequently oral, and the children were called on individually to answer questions and to read aloud (Goyen, 1882). This was generally a traumatic and stressful day for both teacher and student, for not only was the placing of each student critical but the teacher's reputation, salary and career also depended on a satisfactory pass rate. In order to encourage the classes to perform well, teachers were sometimes asked to share in the examination (Petrie, 1885). In some areas parents also observed the examination which, no doubt, increased the stress for pupils as well as teachers.

Although the inspector used the syllabus that had supposedly been covered during the year as a basis for the oral examination of the class, in many cases very little information could be drawn from the pupils. One of the great difficulties with oral class examinations as far as assessing the overall performance of all the students was concerned, was that the more knowledgeable students dominated. Answers were "all too often given by a very small percentage of the class under examination" (Goodwin, 1892, p. 2). Student performance in some subjects was not assessed individually. Instead, the performance of the class as a whole was judged as a measure of the "efficiency" of the teacher. As a result, class subjects were largely neglected in favour of the subjects which "counted" towards the allimportant progression through the standards (Goodwin, 1886). Consequently, individual ability in class subjects, such as science, received no recognition whatsoever.

\section{Secondary Schools}

Before the establishment of the first colleges of the University of New Zealand in 1876 , secondary schools examined their own work to provide some evidence to parents and others of what had been achieved. Because the early settlers needed to be assured that their children were gaining an education comparable with that which they would have received in Britain, this internal assessment was considered by some as "a monstrous thing . . . and the subject of indignant criticism" (Campbell, 1941, p. 113). Those parents who wanted and could afford a university education for their children had to send them away from New Zealand, and consequently a qualification which would gain them entry to an overseas institution came to be a real concern. Any certificate awarded by a New Zealand 
school based on internal assessment was simply not a readily recognised qualification in Britain.

After the establishment of the University of New Zealand in 1876, professors took on the role of examining the secondary schools. The University of New Zealand was originally solely an examining body modelled on the University of London with its affiliated colleges. Any candidate for Matriculation could be admitted as a student after presenting to the Registrar a certificate from a person appointed by the Chancellor that confirmed that the student had received systematic instruction in English grammar and composition, arithmetic, and a number of other subjects including natural philosophy and experimental physics (Thomas, Beeby \& Oram, 1939).

Special examinations were held for scholarship candidates for proficiency. Examiners were appointed by the Chancellor for the different colleges affiliated to the University of New Zealand. The 1876 Calendar for the University of New Zealand listed 23 of these examiners, of whom nine were clergymen and the rest university professors (Thomas et al., 1939). The pupils sat written examinations based on discussions with the teachers of what had been covered during the year. With no moderation in place, the standards were "as various and dissimilar as those institutions themselves" (Beaglehole, 1937, p. 121).

There was not even any consistency between the examinations set for boys and those for girls although they studied ostensibly the same material. Professor Black, examining the students of the Boys' and Girls' High Schools of Otago (Dunedin) in chemistry in 1883, reported that "the paper set to the boys covered the same ground as the chemistry required for junior scholarships of the entrance examination of the University of New Zealand" (Black, 1884, p. 38), whereas the paper set for the girls was "somewhat easier than the boys' paper and required only that material required for the matriculation examination of the University of New Zealand" (Black, 1884, p. 38). This appears to be an early example of an affirmative action policy to encourage girls to study science, although it may also attest to a misguided belief that girls were less capable of understanding science than boys.

For those who did not intend to go to university, employment in the civil service was an attractive alternative - particularly in a predominantly agricultural economy where life for the majority of the population was dominated by hard physical labour. To gain entry into this job sector, students took the Junior Civil Service Entrance Examination. This examination was set up as a qualification accessible to all talented pupils irrespective of whether they went to school in the more affluent towns or in rural areas to secondary school, or the upper standards of the primary school when there were no suitable facilities for secondary education (Lee, 1987). Because it was a national examination and only a few students gained a pass initially, it quickly gained the confidence of parents and potential employers as a mark of superior educational achievement. Unlike the Matriculation examination which students either passed or failed, students passing the Civil Service examination were ranked nationally (Lee, 1987).

By 1885 , not only had the number of high schools increased but these schools were also being set up in towns other than those with universities. The consequent increased demand for access to Matriculation together with the variation in assessment standards led the University of New Zealand Senate to propose in 1878 that the examination for Matriculation be identical or similar to the Civil Service Entrance examination. It was argued that the University was not concerned about the state of preparation of the entrants; the focus, instead, was on 
the qualifications with which they made their exit (University of New Zealand Senate Minutes, 1877). In an attempt to remove the role of the University in assessing the performance of school students, Sir Robert Stout, Minister of Education, and William Habens, Inspector-General of Schools, invited secondary headmasters to collaborate with them in devising their own national examination system. The headmasters were reluctant to accept the control of the Department of Education, and at their first national conference held in Nelson in 1888 they chose the Matriculation examination of the University as being the hallmark of a secondary education (Elley \& Livingstone, 1972). Consequently, the problems of a lack of uniform standards for the Matriculation examination and the differentiation caused by having two parallel examinations were overcome by setting a single national examination under the control of a respected, trusted and independent authority - the New Zealand University.

The "desire for social justice and parity of standards had proved sufficiently strong to cause the establishment of a single school leaving examination under the control of a centralised institution" (Elley \& Livingstone, p. 18). Outstanding academic ability continued to be recognised through a system of scholarships. Candidates for either university entrance or scholarship took the same examination but answered a different series of questions. The Junior Civil Service Examination continued to serve as an exit qualification from the upper primary school for those pupils who were not pursuing secondary education. (Lee, 1987).

Not surprisingly, the importance of performing well on these examinations was not lost on the teachers. One inspector reported that teachers could not "help themselves; they [were] driven to make preparation for written examinations as a principal part of their work" (Pope, 1884, p. 28). The teachers were placed in an especially difficult situation.

On the one hand the wishes of the parents, expressed or understood, are urging teachers on to get as many children as possible to pass examinations that give the entrée to some profitable employment, or to a higher social rank; on the other, the University is compelling them, by means of the number and variety of subjects in which candidates for the smaller academical distinctions are required to pass, to devote nearly the whole of their energy to this preparation for written examinations (Pope, 1884, p. 28).

External examinations increasingly dominated the work of the secondary schools even though only a small proportion of the students actually went on to study at a New Zealand university. Matriculation represented a standard of achievement that was universally recognised by employers and as a result, the tension between providing a sound general education for all students and the necessity of preparing more and more students for competitive examinations intensified as the Matriculation and University Scholarship examinations increasingly dominated the work of the high schools. G.M. Thomson, a science teacher at the Otago Boys' and Girls' High Schools, commented that between 1871 and 1896 the examination fiend had become ever more rampant so that teaching was greatly restricted (Otago Girls High School Magazine, 1896).

At the turn of the century, George Hogben, Inspector-General of Schools, pointed out that the majority of children receiving education in the secondary schools in New Zealand spent less than two years in secondary school, and less than one in 20 secondary school leavers went to a university (Hogben, 1903). There 
was clearly a need for another exit qualification more appropriate to those students who did not intend to go on to a university. But it was the Matriculation examination itself that bore the brunt of the criticism. Hogben complained of the "harmful effect of the dominating influence that these examinations exercise over the curriculum of the secondary schools" (Hogben, 1903, p. 9) and looked for alternatives, within the Matriculation examination, in particular, to the largely textbook-based subjects.

A likely candidate as a more practical and relevant science subject for New Zealand was agriculture. The increased crop production to be obtained through the use of chemical fertilisers and a knowledge of soil chemistry would have been useful to a country so dependent on its agricultural economy. This was encouraged at Timaru Boys' High School where agriculture was offered for Matriculation as a lure for farmers' sons (Bennett, 1980). This was however by no means universal; for example, even in farming districts such as Southland, schools did not offer agriculture. Complaints were made that "practically nothing has been done to educate in agriculture our boys who may have a desire to go onto the land ... The agriculture department, through the instructors, have done and are doing a great deal in certain directions, but they are only working on the fringe" (Southland Boys' High School Magazine, 1918, p. 3).

Recognition of ability in agriculture through the Matriculation examination had no particular value to potential employers when farms were family operations assisted by some manual labourers. There was little demand for this subject so it did not acquire much status. Nevertheless, J.E. Strachan, Headmaster of Rangiora High School, strongly endorsed agricultural education. He regarded matriculation as a "poor intellectual diet even for the academically minded minority" (Campbell, 1941 p. 138). Strachan's remark had some validity because the university entrance examination in New Zealand had never been as formidable a test as was the comparable examination in Great Britain. For example, at the outbreak of the second world war, New Zealand had three times as many university students as Great Britain per head of population, and twice as many as Australia (Campbell, 1941, p. 154).

\section{THE ASSESSMENT ESCALATOR CONTINUES TO DESCEND: THE FIRST HALF OF THE TWENTIETH CENTURY}

\section{Primary Schools}

A new curriculum for primary schools, introduced in 1904, included fundamental changes in content and pedagogy. Instruction, particularly in science, was to be more practically focussed and teachers were encouraged to draw up their own programmes of instruction. The most important impact on assessment was that teachers themselves were finally allowed to decide on each student's progression from one standard to the next. Teachers now complained that there was too much emphasis on practical work. The New Zealand Journal of Education editorial in 1903 even suggested that as a result of the strain the new syllabus put on teachers, it was likely that "considerable additions will have to be made to our lunatic asylums" (New Zealand Journal of Education, 1903, p. 217). Liberal government's free place offer of December 1902 enabled students who gained a proficiency certificate at the end of standard six to obtain two years of free secondary education (See I.A. McLaren, NZJES, 1971, pp. 1-23). 
Inspectors continued to examine the sixth standard to limit the number of children who gained proficiency. This put pressure on teachers to help as many of their students as possible to gain these free places with the result that teachers spent so much time preparing for these formal examinations that they were considered to be one of the greatest obstacles to educational progress. However, allowing schools to internally accredit for proficiency inevitably lead to an increase in the number of passes and a resulting lowering of standards. In 1918, school closures because of the Spanish influenza epidemic resulted in head teachers recommending students for passes in the standard six proficiency examination. The overall pass rate suddenly increased by $6 \%$ (Ewing, 1970).

\section{Reshuffling Qualifications in the Secondary Schools}

As increasing numbers of students gained proficiency certificates secondary school student numbers swelled. The civil service could now demand a higher level of achievement for entry so the Junior Civil Service examination was moved to become the exit qualification after two years attendance at a secondary school. Here it regained its status as a leaving examination for those students not intending to proceed to University (Lee, 1987). From 1905, success in the Junior Civil Service examination was also used to gain the student two further years of free schooling as well as gaining recognition as a qualification for employment that was better than that available to primary school leavers with proficiency certificates. Both the Junior Civil Service and Proficiency examinations were readily accepted by the public because they were examined outside the school by impartial examiners. But as the number of students taking the civil service increased, a more selective examination was needed. Because it was no longer needed for selection purposes the standard of the Junior Civil Service examination declined, so that grade inflation from 1904 to 1912 saw the marks needed to pass the compulsory subjects fall from $40 \%$ to $25 \%$ while the total marks required to pass fell from $45 \%$ to $40 \%$ (Lee, 1987). The principle of maintaining a high failure rate to maintain the scarcity of a qualification was then transferred to the Matriculation examination (Lee, 1987).

The burden of a large number of examinations on teachers and students was beginning to be fully recognised. A national education conference convened in 1917 by Dr William Anderson, Director of Education, looked at ways to address perceived problems. Attendees at the conference included representatives from high schools, the Council of Education, the Department of Education, the Public Service Commission, teachers' training colleges, and primary schools. When it was decided that two examinations (public service entrance and university entrance) and issuing of teachers' certificates be placed under control of the Department of Education, the Chancellor of the University of New Zealand, Sir Robert Stout and Professor Macmillan Brown of Canterbury College left the meeting in protest. Although it was finally recommended that university entrance be accredited by schools, teachers and principals who were anxious to broaden the curriculum for their non-university bound students continued to be frustrated by restrictions enforced by the Matriculation examination which the public demanded as an important qualification (Elley \& Livingstone, 1972).

This proposal that schools be permitted to accredit for university entrance was reiterated by the Reichel-Tate Commission in 1925 which claimed that:

the schools are, from a variety of causes, in the grip of the Matriculation

Examination ... the examiners are not concerned in any way with the 
school records of the candidates. They must judge them entirely by the work done in the examination room. Such a system is not entirely in accord with the best educational practice, and it is unfair to the school, the examinee and the examiner (Royal Commission, 1925).

It also meant that many students left school with no qualifications, having failed to matriculate.

In 1934 the Department of Education co-operated with the New Zealand University to attempt to solve the problem by instituting a departmental leaving certificate which was of the same standard as university entrance but which was designed to permit a broader curriculum for those school leavers who did not intend to go on to university. The new certificate was designated School Certificate (Wild, 1954). This lead to the development of at least one course that did not lead to the university entrance examination and nearly always two or more. The girls' secondary schools had a home life course or a commercial course, or both, while the boys' schools had commercial, industrial or agricultural courses. Although School Certificate was intended to be set at a standard comparable to university entrance, nearly $60 \%$ of girls and more than $75 \%$ of boys still took the University Entrance examination instead (Lee, 1987). The basic reason was that a qualification intended only to gain entry to higher education had continued to be demanded as a necessary qualification for jobs in business and for many semi-professional occupations.

Schools were still not satisfied with the changes, however. Participants at the 1936 Secondary Schools Association (SSA) meeting continued to complain about the Matriculation examination. The Association decided unanimously that the curriculum, with its separate examinations in the various science domains, "through prescriptive deference to external examinations ... sectionalises when it should integrate" (Campbell, 1941, p. 131), a comment which would be fairly echoed for the present day unit and achievement standards (Education Forum, 2000). The Association went on to call for the complete abolition of the Matriculation examination in so far as it affected secondary schools (Campbell, 1941). The SSA Executive again recommended a system of accrediting for entrance to the university with an alternative course of study and an associated examination that allowed a broad, diversified, and enriched programme to be developed in schools. The latter suggestion was considered to be more appropriate for non-university bound students. Those who called for accrediting supported their arguments with the claims that examinations were unreliable and that some candidates failed to perform as well as they might have done owing to undue stress.

In 1939 the Secondary Schools Association rejected the scheme being discussed by the New Zealand University, and proposed that entry to higher education should be modified to include students who possessed School Certificate and who had completed one year in the sixth form. The University was reluctant to accept a pre-requisite for entrance that it did not control, but by January 1941 the accrediting scheme was approved. This paved the way for a new School Certificate to be introduced (in 1946) which teachers demanded be in the form of an external examination in order to arbitrate and maintain standards (Elley \& Livingstone, 1972).

School Certificate was originally intended to be taken after four years of secondary schooling with the more capable students taking it after only three. It soon became normal for most, if not all, students to take School Certificate after 
only three years with a consequent lowering of the standards. The more able students thus were deprived of a challenge while complaints were being voiced over the fact that $50 \%$ of students were still unable to gain a pass (Elley \& Livingstone, 1972). Further changes in 1968 allowed passes in single subjects rather than in the whole core of subjects, so that the pass rate in at least one subject increased to $80 \%$ (Openshaw, Lee \& Lee, 1993). Nevertheless, the reality that many students in numerous courses were still unable to gain any recognition of achievement, however meagre, continued to demotivate students and teachers alike.

\section{EXPANDING THE RANGE OF SCHOOL QUALIFICATIONS}

The range of school qualifications was expanded in the late twentieth century and beyond into 2000. In 1969 an internally-assessed Sixth Form Certificate was introduced in parallel with the University Entrance examination. Students continued to take the University Entrance examination even though they did not intend to proceed to university because of the higher status accorded to the former (Elley \& Livingstone, 1972).

By the early 1970s the number of students staying on at school had increased dramatically so that University Entrance was no longer thought to be able to meet the needs of the majority of sixth formers. Many of these students were labelled as "failures" and had no formal evidence of any scholastic achievements. This problem was compounded by the increase in the number of students staying on for a seventh form year in order to study for the University Bursary and Scholarship examinations without any hope of gaining these qualifications. The Post-Primary Teachers' Association began to call for the abolition of all external examinations, and in 1971 the state secondary school principals also voted for the abolition of School Certificate and University Entrance. Minor changes were made, but it was not until the introduction in the late 1990s of unit standards that the examination system was seriously challenged.

In 1998 the New Zealand Qualifications Authority announced a scheme whereby all student learning would be recorded on one document, the National Certificate of Educational Achievement (NZEA). This certificate was designed as a comprehensive record of student competence whether it be at school, technical college or on-the-job training. Hundreds of unit standards have been registered, and many students have begun to collect them. They have proved popular with the training sector because they clearly specify what the student can do. In schools the work for each unit typically takes four to six weeks, with the assessment being carried out by the classroom teacher immediately on completion of the unit or sometimes as the unit is proceeding with moderation in an attempt to bring some degree of consistency. The teachers of students who had been unable to gain a School Certificate pass liked unit standards because they gave students an immediate and attainable goal. Teachers of more able students complained that removing grading resulted in a dumbing down process, however (Hodgetts \& Hodgetts, 1999).

School Certificate normally taken at the end of form five, and bursary examination at the end of form seven, continued to be offered and, not surprisingly, continued to be the preferred method of assessment for all those students who were thought capable of passing. As a consequence the assessment system divided students on the basis of ability, with School Certificate and Bursary having higher status than unit standards. To meet some of the objections 
to unit standards and to try to incorporate some of the perceived benefits of traditional examinations the New Zealand Qualifications Authority (NZQA) introduced yet another method of assessment.

The 2001 Achievement Standards are NZQA's latest attempt to try to measure what students have learnt from their time in school in all the school subjects and to respond to some of the criticisms of unit standards. Starting in 2002, this system of standards will replace School Certificate. In 2003 achievement standards will also replace Sixth Form Certificate, and in 2004 it is proposed that University Bursary examinations will disappear. The knowledge that students are expected to acquire in each subject during the course of a year's study is broken down into a number of units. This number varies from subject to subject and from year to year, but is typically six or seven. At least half of the standards for any subject are to be assessed internally, with external examinations retained for the remainder. For each standard the required performance indicators are specified at three different levels. This is intended to overcome the problem with unit standards where high performing students were not challenged with a simple pass/fail system designed so that most could pass. Each standard must stand alone so that a student can choose to be examined only in a single standard. The most able students are expected to achieve at the highest of the three levels, labelled "excellence". However, with the requirement that each standard be self contained, the opportunity to assess the students' ability to integrate information across domains, something at which able students outperform their less able peers, is lost. These achievement standards are designed such that $20 \%$ of students will gain passes at the excellence level.

\section{CONCLUSIONS}

A consideration of the history of assessment in New Zealand shows that to be successful a qualification needs to have a certain scarcity value. It also needs to have consistency and reliability in order to be accepted by parents, employers and tertiary institutions and has to have a national level of uniformity, minimal internal assessment, and a credibility outside New Zealand. Concerns for social justice and equity which demand that the educational achievement of all students is recognised in a comparable manner reduces the scarcity value of certain qualifications, and it is predicted that schools and parents will look elsewhere for higher level qualifications (Morris, 2000). Fragmenting the content of Achievement Standards into small enough units such that some are attainable by all students who apply themselves negates the rarity value of the achievement. Significant amounts of internal assessment, even with attempts at moderation across schools, compromises the possibility of uniformity and consistency at a national level. Finally, the complex nature of the NCEA would seem to compromise its likely credibility outside New Zealand. The introduction of NCEA and the abolition of School Certificate and Bursary and Scholarship examinations is one further example of standing firmly on a downward moving escalator while those seeking recognition for their most able students endeavour to scramble to a higher step. 


\section{REFERENCES}

Beeby, C. E. (1938). Examinations in New Zealand. Yearbook of Education.

Beaglehole, J. C. (1937). The University of New Zealand, Wellington. New Zealand Council for Educational Research.

Bennett, F. O. (1980). A Canterbury Tale. Wellington: Oxford University Press.

Black, J. (1884). Examiner's report of the boys' and girls' high schools of Otago. Appendices to the Journals of the House of Representatives (AJHR), E1b. p. 38.

Campbell, A. E. (1941). Educating New Zealand. Wellington: Department of Internal Affairs.

Elley, W. B. \& Livingstone, I. D. (1972). External examinations and internal assessment. Wellington: New Zealand Council for Educational Research.

Ewing, J. L. (1970). Development of the New Zealand primary school curriculum, 18771970. Wellington: New Zealand Council for Educational Research.

Goodwin, J.S. (1886). Inspector's report for Auckland. Appendices to the Journals of the House of Representatives, E1b, p. 4.

Goodwin, J. S. (1892). Inspector's report for Auckland. Appendices to the Journals of the House of Representatives, E1b p. 2.

Hodgetts, I. \& Hodgetts, D. (1999). Qualifications, critiques, and reforms: The rhetoric surrounding the New Zealand Qualifications Authority. Waikato Journal of Education, 5, 34- 49.

Hogben, G. (1903). Report of the Inspector General of Schools. Appendices to the Journals of the House of Representatives, E12, p. 7.

Irwin, M. D. R. (2000). Policy directions for school qualifications. Auckland: Education Forum.

Lee, H. (1987). The junior civil service examination reconsidered. In R. Openshaw and D. McKenzie (Eds.) Reinterpreting the educational past: Essays in the history of New Zealand education. Wellington: New Zealand Council for Educational Research.

Morris, J. (2000, June 23). Levelling tall poppies: Current educational trends. Should we be worried? Speech to National Party breakfast meeting, Epsom. Policy directions for school qualifications. Auckland: Education Forum.

New Zealand Journal of Education. (1903, December). Editorial. Dec, 217-218.

Otago Girls' High School, School Magazine (1896, May 7). 6 p. 823.

Petrie, D. (1885). Inspectors Report for Otago. Appendices to the Journals of the House of Representatives, E1b, p. 40.

Pope, J. H. (1884). Inspector's Report, Appendices to the Journals of the House of Representatives, E9, p. 28.

Report of the Royal Commission on University Entrance in New Zealand (1925). AJHR, E-7A. Wellington: Government Printer, 22-23.

Royal Commission (1925). Report on University Entrance in New Zealand. Wellington, Government Printer.

Standards of Education and Inspection of Schools (1878, September). New Zealand Gazette, 92(26).

Thomas, W., Beeby, C.E., \& Oram, M. H. (1939). Entrance to the university. Wellington: New Zealand Council for Educational Research.

Taylor, W. (1883). Inspector's Report for Otago. Appendices to the Journals of the House of Representatives, E1b, p. 32.

G. V. Wild (1954). Accrediting for University Entrance in New Zealand. Education News, 4 (8), 7. 